\title{
Włodzimierz Czarnecki, Szlachta chetmska. Od Bobrowskich do Zamojskich w późnym średniowieczu i wczesnej nowożytności (Wybrane rodziny), Studio KROPKA, Stary Toruń 2018, ss. 340
}

Szlachta czy też rycerstwo jako grupa społeczna, bardzo często poddawana była wielowymiarowym badaniom, w których szczególną uwagę zwracano na sprawy genealogiczne, osadnicze, majątkowe, wyznaniowe czy polityczne.

Prac takich można odnaleźć bardzo wiele a jako przykład można tu wskazać choćby opracowania Jacka Pielasa ${ }^{1}$, Edwarda Opalińskiego ${ }^{2}$, Bartosza Drzewieckiego $^{3}$, Sławomira Wróblewskiego ${ }^{4}$ czy Mariusza Lubczyńskiego ${ }^{5}$. Bliskie temu zagadnieniu są również monografie konkretnych rodów szlacheckich w tym:

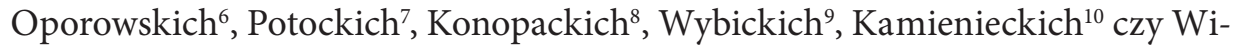
śniowieckich ${ }^{11}$.

Szlachta chełmska nie doczekała się wielu opracowań, co wynika zapewne z jej peryferyjnej lokalizacji oraz silnego rozrodzenia znajdujących się na tery-

1 J. Pielas, Oleśniccy herbu Dębno w XVI-XVII wieku. Studium z dziejów zamożnej szlachty doby nowożytnej, Kielce 2007; tegoż, Podziały majątkowe szlachty koronnej w XVII wieku, Kielce 2013; Akty podziałów dóbr ziemskich szlachty sandomierskiej z XVII wieku, wstęp i oprac. J. Pielas, Kielce 2014.

2 E. Opaliński, Elita władzy w województwach poznańskim i kaliskim za Zygmunta III, Poznań 1981; tegoż, Kultura polityczna szlachty polskiej w latach 1587-1652, Warszawa 1995; tegoż, Rodziny wielkosenatorskie w Wielkopolsce, na Kujawach i na Mazowszu za Zygmunta III. Podstawy karier, Warszawa 2007.

3 B. Drzewiecki, Szlachta województwa chetmińskiego w latach 1454-1772. Mobilność spoteczna i terytorialna, Warszawa 2014.

4 S. Wróblewski, Rycerstwo ziemi sądeckiej w średniowieczu, Kraków 2016.

5 M. Lubczyński, Szlachta powiatu ksiąskiego za ostatnich Jagiellonów. Struktura majątkowa, Warszawa-Bellerive-sur-Allier 2016.

6 T. Pietras, Oporowscy herbu Sulima. Kariera rodziny możnowładczej w późnośredniowiecznej Polsce, Łódź 2013.

7 M. Wolski, Potoccy herbu Pilawa do początku XVII wieku. Studium genealogiczno-własnościowe, Kraków 2013.

8 W. Nowosad, Konopaccy herbu Odwaga - dzieje pomorskiej rodziny senatorskiej $w$ XVIXVII wieku. Studium genealogiczno-majątkowe, Warszawa 2014.

9 J. Kowalkowski, Wybiccy herbu Rogala od XVI do XX wieku. Studium genealogiczno-majatkowe, Warszawa 2015.

${ }^{10}$ K. Niemczyk, Kamienieccy herbu Pilawa. $Z$ dziejów kariery i awansu szlachty polskiej do 1535/1536 roku, Katowice 2016.

11 I. Czmańska, Wiśniowieccy. Monografia rodu, Poznań 2007. 
torium ziemi chełmskiej rodzin szlacheckich. Taka sytuacja, choć stwarza szerokie pole możliwości badań naukowych i wzbogacenia historiografii o nowe ustalenia, wymaga od zajmującego się nią historyka zmierzenia z rozległym materiałem źródłowym i szczątkowymi informacjami rozproszonymi po wielu zespołach archiwalnych. $Z$ tym trudnym zadaniem zmierzył się Wiesław Bondyra, analizujący kwestie majątkowe, migracyjne i polityczne szlachty chełmskiej w okresie nowożytnym ${ }^{12}$. Włodzimierz Czarnecki swoimi badaniami obejmuje czasy wcześniejsze, czyli okres późnego średniowiecza i wczesnej nowożytności (XV-XVI w.). Jest to moment szczególny z uwagi na zmiany zachodzące w strukturze stanowej i pojawiające się nowe rody szlacheckie. Prace W. Czarneckiego, o czym pisze sam autor, mają charakter szkiców genealogiczno-osadniczych, opracowujących drobiazgowo sytuację majątkowo-społeczną i zawiłe powiązania między rodzinami wynikłe z praw własności, dziedziczenia czy dzierżawy tych samych wsi. Autor wydaje je w serii tematycznej, w której do tej pory ukazały się trzy tomy. W każdym z nich W. Czarnecki opracował 20 rodzin posiadających majątki w ziemi chełmskiej ${ }^{13}$.

Recenzowana monografia jest tomem trzecim, wydanym w 2018 r. Omawiane są w niej kolejne, ułożone w układzie alfabetycznym parantele szlacheckie: Bobrowscy, Depułtyccy, tenutariusze Depułtycz Królewskich, Gorzkowscy, dziedzice Hajowników, tenutariusze Leśniowic, dziedzice lubomelskiego Łukowa, dziedzice Maszowa, Mogielniccy, dziedzice Okunina i Mokowa, dziedzice Orchowca, Orzechowscy, Rudniccy, Skorutowie, dziedzice Sosnowicy, dziedzice Tarzymiechów, dziedzice Tworyczowa, Wiśniowscy, dziedzice Wołkowyj oraz Zamojscy. Pierwszą rzeczą, która nasuwa się na myśl już po wstępnej lekturze

${ }_{12}$ Zob. W. Bondyra, Reprezentacja sejmowa Rusi Czerwonej w czasach saskich, Lublin 2005; tegoż, Własność ziemska w województwie bełskim w czasach saskich, Lublin 2015; tegoż, Starostowie chetmscy w XVI w. Charakterystyka grupy, „Annales UMCS”, Sectio F, t. 46/47, 1994; tegoż, Kariery polityczne szlacheckich wychowanków Akademii Zamojskiej z Rusi Czerwonej w dobie saskiej, [w:] W kręgu akademickiego Zamościa, Lublin 1996; tegoż, Migracje szlachty czerwonoruskiej $w$ dobie saskiej, [w:] Sąsiedztwo. Osadnictwo na pograniczu etnicznym polsko-ukraińskim $w$ dobie nowożytnej, Rzeszów 1997; tegoż, Testament Franciszka Węgleńskiego podkomorzego chelmskiego z 1750 r. Przyczynek do dziejów szlachty chetmskiej, „Res Historica”, t. 17, 2004; tegoż, Działalność polityczna Sapiehów na Rusi Czerwonej w czasach saskich, [w:] Sapiehowie epoki Kodnia i Krasiczyna, Lublin 2007; tegoż, Ostatni przedstawiciele rodu Żółkiewskich w Żółkiewce w XVII i I połowie XVIII w., [w:] Żółkiewscy w ziemi chełmskiej, Żółkiewka 2011.

${ }_{13}$ W. Czarnecki, Szlachta ziemi chetmskiej do połowy XVI wieku, Białystok 2012; tegoż, Nobiles Chelmenses. Wybrane rodziny w późnym średniowieczu i wczesnej nowożytności. Studia osadniczo-genealogiczne, Stary Toruń 2016. 
to niesprecyzowany przedmiot badań w tytule monografii. Tytuł opracowania brzmi bardzo ogólnie i daje czytelnikowi mylne wrażenie, że szlachta została opracowana we wszystkich aspektach. Jedynie w spisie treści, część poświęcona rodzinom jest opisana jako „Szlachta chełmska i jej majątki”. Owszem autor analizuje familie szlacheckie, ale głównie w kontekście osadniczym i majątkowym, genealogia schodzi na plan dalszy, a innych dziedzin działalności po prostu brakuje. Nie ma natomiast wyszczególnienia, że tak duża uwaga została poświęcona kwestiom majątkowym i migracyjnym. Takie ujęcie tematu jest mylące, szczególnie dla osoby, która poszukuje informacji choćby o aktywności politycznej czy religijnej. Kolejną istotną sprawą jest brak konsekwencji przy prezentowaniu poszczególnych rodzin. Zamiast ujednolicenia opisów wyłącznie do danej rodziny mamy podział na trzy grupy: konkretnego rodu, dziedziców danej wsi i tenutariuszy. Jest to dość dziwny zabieg, który występował już we wcześniejszych pracach W. Czarneckiego ${ }^{14}$.

We wstępie autor omówił najważniejsze założenia szkicu oraz stan badań. Nie podał natomiast, w jaki sposób korzystał ze źródeł i jak pomogły mu w analizie podjętego $\mathrm{w}$ temacie zagadnienia, a nawet ich nie wymienia. Informacje o wykorzystanych źródłach znajdują się w przypisach, wykazie skrótów i bibliografii. Nawet jeśli powyższa książka jest kolejnym tomem w serii, to informacja o tym, czy dalej korzystano z tej samej bazy źródłowej, czy pojawiły się w niej nowe pozycje, powinna znaleźć się we wstępie.

Opisy wybranych rodzin są opracowane wyjątkowo drobiazgowo i z dbałością o najdrobniejsze szczegóły. Widać w tym mrówczą pracę, jaką wykonał autor przy zbieraniu informacji. Z ogromną skrupulatnością został przedstawiony proces nabywania, rozdrabniania i przekazywania dóbr szlacheckich, co mogą wykorzystać w swoich badaniach osoby piszące monografie wsi, miasteczek czy gmin. Ważne jest też, że praca dotyczy tzw. mikrohistorii i pozwala poznać z tej perspektywy tkankę społeczną ziemi chełmskiej. Odkrywa ona zupełnie nowe informacje, choćby o stanie posiadania poszczególnych członków rodzin czy wyjaśnia genezę otrzymania przez nie szlachectwa. Dobrym przykładem jest rodzina Orchowskich. W. Czarnecki nie tylko odkrył ich pierwszych przedstawicieli, ale dokładnie opracował i przedstawił historię należącego do nich gniazda rodowego - Orchowca. Niestety, nie wszystkie opisy są jednakowe pod względem zawartych informacji. O ile w przypadku Depułtyckich, Orchowskich

${ }^{14}$ Zob. W. Czarnecki, Szlachta ziemi chetmskiej, s. 71-360. Oprócz nazwy rodziny pojawiają się też dziedzice danych miejscowości. 
czy Zamojskich w książce znajdziemy fragmenty dotyczące pochodzenia danej rodziny, to w części opisów autor z nich zrezygnował i od razu przeszedł do gruntownego omawiania spraw majątkowych.

Autor nie podjął się także weryfikacji informacji zawartych w herbarzach ${ }^{15}$, szczególnie w zakresie podanych w nich informacji o powiązaniach genealogicznych konkretnych rodzin. Do dzisiaj są one jednym z ważniejszych źródeł informacji dla historyków, a zawierają wiele niezweryfikowanych informacji, przez co mogą wprowadzać w błąd. Przykładem jest choćby postać Aleksandra Koniecpolskiego, wojewody sandomierskiego. Kasper Niesiecki napisał, że miał on jednego syna Stanisława, natomiast faktycznie posiadał on dwóch: Samuela i Stanisława ${ }^{16}$. Przekłamanie pojawia się również w przypadku liczby żon księcia Michała Jerzego Czartoryskiego, których K. Niesiecki wymienił cztery a w rzeczywistości były trzy ${ }^{17}$.

Autor korzystał z licznych rękopisów znajdujących się w Archiwum Głównym Akt Dawnych, Archiwum Archidiecezjalnym w Lublinie, Archiwum Państwowym w Lublinie i Centralnym Państwowym Archiwum Historycznym Ukrainy we Lwowie oraz rękopiśmiennych materiałów w zasobach bibliotek: Narodowej Akademii Nauk Ukrainy we Lwowie, Czartoryskich w Krakowie, Katolickiego Uniwersytetu Lubelskiego, Hieronima Łopacińskiego w Lublinie, Narodowej w Warszawie, Ossolińskich we Wrocławiu i Polskiej Akademii Nauk w Krakowie. Najwięcej wykorzystanych materiałów pochodzi z lubelskiego Archiwum Archidiecezjalnego i Archiwum Państwowego w Lublinie. W tym pierwszym przypadku autor analizował dokumenty pergaminowe oraz księgi wizytacji diecezji chełmskiej i konsystorza chełmskiego. Z zasobu Archiwum Państwowego w Lublinie wykorzystał przede wszystkim zawartość ksiąg ziemskich chełmskich (zapisy, wyroki), krasnostawskich (zapisy, wyroki) i lubelskich, grodzkich chełmskich (zapisy, relacje) oraz podkomorskich lubelskich, a także dodatkowo dokumentów miast Siedliszcze i Uchanie, aktów Kolegiaty Zamojskiej, dokumentów Chełmskiego Konsystorza Greckokatolickiego i parafii rzymskokatolickich (Czułczyce, Krasnobród, Kumów, Siennica, Sitaniec, Skier-

15 Zob. K. Niesiecki, Herbarz polski, wyd. J.N. Bobrowicz, t. 1-10, Lipsk 1839-1845; S. Uruski, Rodzina. Herbarz szlachty polskiej, t. 1-16, Warszawa 1904-1932; A. Boniecki, Herbarz polski, t. 1-16, Warszawa 1899-1913.

${ }_{16}$ Por. K. Niesiecki, Herbarz, t. 5, Lipsk 1840, s. 200; A. Przyboś, Koniecpolski Aleksander, [w:] Polski słownik biograficzny (dalej PSB), t. 13, Wrocław 1967-68, s. 513-516.

17 Por. K. Niesiecki, Herbarz, t. 3, Lipsk 1839, s. 233 i K. Piwarski, Czartoryski Michał Jerzy, [w:] PSB, t. 4, Kraków 1937, s. 287-288. 
bieszów i Szczebrzeszyn). Pracochłonna kwerenda w niełatwym obszarze ksiąg ziemskich umożliwiła W. Czarneckiemu uchwycenie wielu szczegółowych informacji o wysokości zadłużenia i posagów, transakcjach i spadkach oraz udziału w nabywaniu, zbywaniu i wykorzystywaniu dóbr przez członków omawianej rodziny.

Konstrukcja pracy wygląda następująco: treść właściwą poprzedza wstęp, następnie przechodzimy do zasadniczej części, czyli opisów wspomnianych rodzin, a w dalszej kolejności do zakończenia, streszczenia w języku angielskim, wykazu skrótów, wykazu źródeł, aneksu w postaci tablic genealogicznych i indeksu osobowego. Nie mamy podziału na rozdziały a poszczególne fragmenty oddzielają jedynie nazwy poszczególnych rodzin. Uwagę zwraca brak pełnej bibliografii, ograniczonej jedynie do wykazu źródeł rękopiśmiennych i drukowanych. Pominięto wykorzystane opracowania, choć pojawiają się one w pracy ${ }^{18}$.

Kolejnym brakiem i to dość istotnym w przypadku opracowania dotyczącego kwestii osadniczych i migracyjnych jest brak indeksu geograficznego obok osobowego. Taki indeks jest ważny z racji omawiania w książce zagadnień stanu majątkowego szlachty. Z technicznych uwag wydaje się, że można było zdecydowanie lepiej podkreślić nazwę danej rodziny w tekście. Co prawda wykorzystano pogrubioną czcionkę i inicjały wpuszczone w tekst, ale być może należało to ukazać w bardziej czytelnej formie graficznej, co stanowiłoby odpowiednią granicę pomiędzy końcem jednego opisu a początkiem drugiego. Podobnie jest $\mathrm{z}$ osobami reprezentującymi daną rodzinę. Kluczowe postacie można było podkreślić, bo brak tego powoduje, że tekst zlewa się w jeden, nieustanny ciąg informacyjny, wywołując u czytelnika poczucie zagubienia. Aneks w postaci tablic genealogicznych jest przydatnym elementem, ułatwiającym rozwikłanie skomplikowanych afiliacji rodzinnych chełmskiej szlachty.

Praca jest napisana językiem zrozumiałym, aczkolwiek zawierającym dość skomplikowane zwroty. Problemem jest sposób narracji, w której autor podaje naraz za dużo informacji, czasem dość mocno przeskakując po zagadnieniach, co w pewnym momencie powoduje zgubienie się w czytanym tekście. W pewnych momentach przypomina ona rozbudowane sprawozdanie $\mathrm{z}$ tego, co autorowi udało się odnaleźć w źródłach. Być może taki sposób przedstawiania historii bliski jest autorowi, odbiorca jednak, szczególnie niebędący mediewistą, może mieć problem ze zrozumieniem treści. Korekta nie ustrzegła się kilku błędów językowych. Na s. 15 jest „Wiśniów” a powinno być „Wiśniowie”, na s. 34

\footnotetext{
18 Zob. Depułtyccy herbu Pomian (W. Czarnecki, Szlachta ziemi chetmskiej, s. 33).
} 
jest „biskup” a powinno być „,biskupa”, na s. 91 jest „Maciej” a powinno być „Macieja”, na s. 172 na s. 210 jest „Trnogóra” a powinno być „Tarnogóra”, a na s. 254 jest „Zamijskich” a powinno być „Zamojskich”.

Praca autorstwa W. Czarneckiego to solidne studium źródłowe, mające praktyczny walor, szczególnie dla osób zajmujących się badaniami prozopograficznymi, biografistyką, genealogią, osadnictwem, migracjami oraz sprawami majątkowymi. Dla innych może okazać się zbyt ciężka z uwagi na sposób narracji, skomplikowaną treść czy specjalistyczny język. Natomiast trzeba zwrócić uwagę, że praca W. Czarneckiego pomimo pewnych braków ma charakter naukowy i odkrywa nieznane dotąd fakty w obszarze spraw majątkowych chełmskiej szlachty. Poza oczywistym walorem informacyjnym, możemy zapoznać się z warsztatem naukowym historyka mediewisty, badającego ruchy osadnicze i społeczność szlachecką. Biorąc pod uwagę obszar ziemi chełmskiej, której szlachta wciąż wymaga gruntownych badań, kolejne tomy opracowania W. Czarneckiego stają się nieocenionym źródłem wiedzy do jej dziejów. 